\title{
Agile Software Development: Reusability and Customizability is key to Competitive Advantage
}

\author{
Yogita Patra, Shruti Tripathi
}

\begin{abstract}
The study addresses the research issue of how software firms can compete in a dynamic industry through creating agile software development processes. It gives an insight into what a firm needs to do to equip its software process engineers to create flexible processes which can be customized specifically for the customer or reused for another customer without having to recreate them. Can these perceived process dimensions impact the competitive advantage of the firm? Survey design was used to collect responses from 100 software firms. Senior managers in the delivery departments were taken as respondents. The model and hypothesis were assessed on AMOS using structural equation modelling for path analysis. The results suggested that firms that can reuse the codes and customize the services specific to customers through training and development initiatives taken for employees are able to create competitive advantage in the industry. The improvement in the processes be having direct impact on the economic efficiency of the firm.
\end{abstract}

Index Terms: Competitive advantage, Software development, Training and development, Structural Equation Modelling.

\section{INTRODUCTION}

The role of $\mathrm{HR}$ as a strategic partner had long been recognized by researchers who emphasized on the strategic bent of human resource management. The requirement of transition from personal management role to strategic one is a necessity in the competitive business environment [1]. Many previous studies have been conducted on the strategic role of HR and its impact on the internal environment of the organization both at the micro i.e individual or group of employees as well as on the macro i.e business unit or organizational level. Less attention has been perceived by role of policy and decision making by strategic HR on the external environment faced by the organization. The present study tries to understand the link between the two aspects. The paradigm shifts of HR from paper pusher to policy pusher and now reserving a chair in the Board.

Dynamic IT industry business environment has forced organizations into lower margins and higher cost pressures. HR's focus needs significant shift to employee productivity and commitment where people are looked at as a source of competitive advantage. Studies investigated the impact of HR processes like training and development, performance management, performance appraisals, career management on the employees, totally ignoring the organizational factors that can enhance the result outputs of how these functions work.

Revised Manuscript Received on June 15, 2019

Yogita Patra, Shruti Tripathi, Amity University, Noida India.

Researchers in this study have tried to answer these questions in the IT industry and results can be replicated in the other industries as well- (i) Does strategic role of human resource management contribute to competitive advantage of the organization? (ii) Does Strategic role of HR influence/ support training and development focus in the organization? (iii) Does training and development focus has any impact on the competitive advantage of the firm?

A survey-based analysis was done on 100 IT organizations, which have been functional for a minimum period of 5 years 205 participants responded to the survey and results compiled and analyzed in the later sections. Researchers [2], postulated components of perceived competitive advantage as process flexibility and process predictability. They emphasized that reusability and customizability of the processes as per the dynamic changing business environment is the key to optimum performance by the organization. Many researchers have tested the relationship between strategic HR orientation and firm's performance [3] or competitive advantage [4], but research on the antecedents is lacking which impact the competitive advantage of the firm when the organization has a strategically aligned HR function. There are limitations of the resource-based view of the firm where it is unable to explain, what makes these resources competitive. Researchers feel that the previous studies suffer from omitted variable bias.

The present research tries to answer how strategic HR influences training and development focus in the organization to enhance competitiveness of the firm. Researchers had argued that the present fit between business and strategic HR may be apt for current performance but for future growth HR needs to create the flexibility which will equip it to respond to changes in the business environment effectively.

\section{LITERATURE REVIEW}

\section{Trajectory of HRM in India: Last 100 years}

In early 1920s Tata group had introduced employee welfare policies like provident fund, leave rules in India. With formation of Trade Union Act in 1926 came the recognition for industrial relations. Factories Act of 1948 further streamlined the welfare policies of employees which had sown the seeds of personal management in India. By 1960s Indian Institute of Personal Management and National Institute of Labour Management was set up to streamline things further. It was only by 1970 s that the greater role of HR was slightly recognized in enhancing organizational effectiveness. By 1980s setting up of two bodies, National Human Resource Development Network and Academy of Human Resource Development further established the 
confidence in human resources to outperform its boundaries from personal management to employee development orientation [1]. After the liberalization of economic policies and phenomenal surge in the IT industry coerced human resource management to develop employees to be future ready to compete with the foreign firms.

By 2000, industry practitioners and researchers both identified and agreed on the importance of skilled employees for the economic success of an organization. There are meta-theories which emphasize that evolution of HRM should be linked to the healthy performance of the organization and there are middle level process theories which state how these two should be linked [5]. The most embraced meta theory is resource-based view of the organization. The attention received by resource-based view (RBV) predicts the relation between the specific nurtured resources of the organization and its sustainable competitive advantage. The resources are rare, non-substitutable and uncopiable and hence great source of competitive advantage in the market [6].

Defining strategic management, "Strategic management is a continuous iterative process aimed at keeping an organization as a whole appropriately matched to its environment" [7]

\section{Theories of Strategic management}

Three main roots of strategic management are: economics, psychology and sociology. As per [8], transaction cost theory, agency theory, evolutionary economics and resource-based view of the organization relate to the economic root. Rest of the two are not in the purview of this study and hence not explained. Based on the further study by researchers, concept of internal organization was introduced which implies that process, routines, internal practices and their successful implementation can create competitive advantage for the firm. This creates superior performance which is resultant of either Monopoly, Ricardian or Schumpeterian rents [9]. IT industry now does not have the benefit of a monopoly market anymore. The competition has grown strong and margins are pressed. It is now imperative for organizations to move towards creating Ricardian rents by generating organization specific resources which are intangible in terms of their knowledge, leadership and Schumpeterian rents which have an advantage of being innovative by process renewals.

H1a: Strategic role of HR positively impacts the competitive advantage of the organization.

\section{Training \& Development as a tool to create competitive advantage}

The tool can be looked at from three perspectives: firstly, how strategic orientation of HR influences the decision to invest in training and development when the human capital is low. Secondly, how should training and development activities be planned to get maximum ROI as it is a huge cost to the organization. Thirdly, the choice of best practices to implement training and development plan. Small organizations mostly rely on 'on-the-job' (OJT) trainings due to low cost involved. It comes with a disadvantage of being ad-hoc and prone to errors. There is low possibility of proper evaluation of the employee except the personal judgement of the supervisor. On the other hand, planned or embedded training programs are a huge cost to the organization. The stakeholders need to know the extended benefits in the long term for the organization. They expect quantified results. The aim and attempt should be to skill 'the right people in the right place, with the right attitude and the right skills' [10].

H1b: Strategic role of HR positively impacts training and development focus in the organization.

$\mathrm{H} 2 \mathrm{a}$ : Training and development positively impacts innovation capabilities of the employees.

$\mathrm{H} 2 \mathrm{~b}$ : Training and development positively impacts reusability of established processes in other similar projects.

$\mathrm{H} 2 \mathrm{c}$ : Training and development positively impacts customizability of processes as per client needs.

\section{Theories of Competitive Advantage}

Competitive advantage can be acquired when an organization invests in certain set of attributes that helps in outperforming the competitors. There are two main theories of competitive advantage: Market-based view (MBV) and Resource-based view (RBV). Two most popular theories of $\mathrm{MBV}$ are proposed by Structure-Conduct-Performance framework by Bain in 1968 and five forces model by Porter in 1980. As per this view organizational performance are governed by the competitive dynamics of the industry/environment it operates in. RBV will be discussed in detail in the next section. Further from RBV, knowledge-based view and capability-based view have been derived. Recently, relational view of strategy and transient advantage also have gained popularity, but we will restrict our discussion to the resource-based view and capability-based view for this study [11].

\section{Resource-based view of competitive advantage}

The term resource-based view' was coined by Wernerfelt in 1984. The RBV theory reiterates that the resources possessed and deployed by the organization are equally if not less important than other success factors of the organization. Early researchers classified resources based on skill, knowledge and technological know-how they possessed. The organizations which can leverage their resources in these three arenas which the current competitors are not able to replicate immediately are able to gain an edge. Researchers provided a perspective that internal resources cannot be taken as a standalone success provider, organizations will have to develop them as per the market requirement.

\section{Capability based view of competitive advantage}

Competitive advantage is provided by resources of the organization which have distinct capabilities. He proposed four categories of capabilities that the organizations should focus on: cross-functional, broad-functional, activity-related and specialized capabilities. The concept is context specific and is valid for each organization as per the environment it exists. The researchers argue that there is no generalist approach to which kind of capability development should be prioritized by the organizations. Thus far it has been analyzed that distinct capability provides competitive advantage. Training and development enable organizations to develop capabilities which are inimitable [12]. The advantage can be built by investing in the training and development. The strategic orientation of the human resource department impacts the decision to 
launch T \& D initiatives for capacity building.

H3a: Innovation skills of employees positively impact competitive advantage of the organization.

H3a: Reusability of established processes positively impact competitive advantage of the organization.

H3a: Customizability of processes as per client needs positively impact competitive advantage of the organization.

Perceived competitive performance factors in IT Industry Just like in manufacturing, software industry also can be perceived to have competitive advantage if it responds to two aspects efficiently: product cost efficiency and customer responsiveness. While there can be number of ways to enhance performance of a software organization, this research discusses the approach towards processes taken across projects for implementation. The two key factors that contribute to the efficiency and effectiveness are "replicable' processes and organization's capability to 'tailor-make' it as per the specification of the customers. Processes that are replicable enhance the process predictability. HR can assign the resources required as the path of the process is known and is repeated. This clearly gives an edge to the firm as the process has been developed internally and has proven result-oriented track record. The tailor-made processes enhance effectiveness by predicting the speed with which an organization responds and fulfils the change required from the customer end.

Product-cost efficiency: is achieved by a software firm when it produces its product with relative efficiency in the minimum cost as compared to its competitors. The more the organizations can use their replicable processes the more efficient they become by saving cost and time both [13].

Customer responsiveness: The organization's capability to cater to demand fluctuations and specifications for the products that they have been producing in mass as per the customers. Organizations depend on the capability of the organization to tailor-made solutions for the customers if they want to boast of being customer responsive [2].

\section{RESEARCH METHODOLOGY}

The research questions were investigated through the inputs from the IT industry professionals. IT delivery professionals with designation of manager and above were selected by convenience sampling. Hypothesis was developed from the research questions as stated in previous sections. Based on literature review a model framework has been proposed in Figure 1. The hypothesis addresses the relationship between strategic role of HR and competitive advantage, mediating influence of training and development focus on competitive advantage of the organization. The research relating strategic role of $\mathrm{HR}$ and competitive advantage exists.

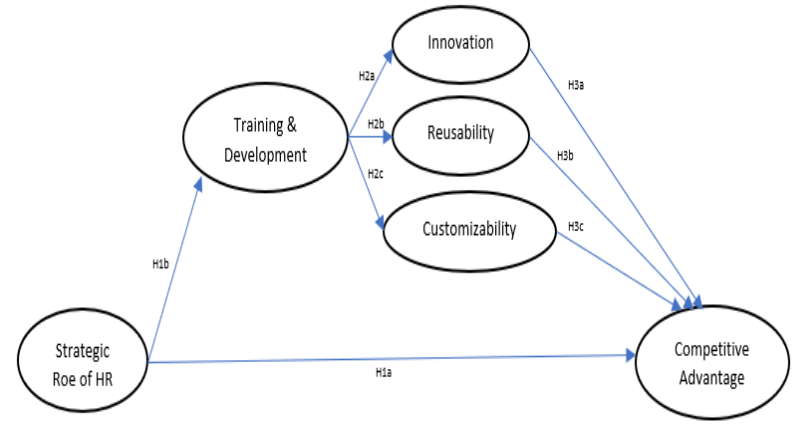

Fig 1: Model framework proposed by authors

Sampling and Data Collection: Quantification of training and development and competitive advantage was modelled through its sub-constituents as shown in Figure I. Data was collected using a survey-based questionnaire addressed to the software process engineers and workforce planning professionals working in the IT industry with the guarantee of anonymity. The professionals with at least five years of work experience with the same organization were selected. The survey questionnaire was mailed to a sample of top 100 IT firms which have their operations in domestic as well as international markets. Care was taken to provide equitable representation to firms of all sizes.

From the total 260 responses received, sample of 205 usable responses was taken into consideration. Organizations with less than 4,000 employees were excluded from the sample. The total employee headcount range taken was minimum 4,000 to greater than 100,000 . A non-parametric Kolmogorov-Smirnov test was conducted to test normality of the data. The p-values were found to be significant, hence null hypothesis rejected; it was concluded that the sample distribution is normal. The demographic aspects of the survey sample are stated in Table 1.

Table 1: Demographic aspect of the survey sample

\begin{tabular}{|l|r|r|}
\hline \multicolumn{1}{|c|}{ Aspect } & Mean & \multicolumn{1}{c|}{ S.D. } \\
\hline $\begin{array}{l}\text { Total number of years in IT } \\
\text { Industry }\end{array}$ & 18.6 & 16.4 \\
\hline Total Headcount & 1012.8 & 1890.1 \\
\hline Annual Revenue (\$ million) & 2.5 & 1.5 \\
\hline $\begin{array}{l}\text { Number of new customers added } \\
\text { per year }\end{array}$ & 31.1 & 74.5 \\
\hline $\begin{array}{l}\text { Number of old customers retained } \\
\text { per year }\end{array}$ & 48.2 & 52.1 \\
\hline $\begin{array}{l}\text { Number of new products } \\
\text { introduced per year }\end{array}$ & & \\
\hline
\end{tabular}

Research Instrument and Reliability: There was no missing data in the study as survey required respondents to answer each question before submitting the responses. The scale used was a 5-point item scale asking respondents to rate from Strongly agree to Strongly disagree. The scale for competitive advantage was adopted from [2] training and development was 
adopted from [14], strategic role of HR was adopted from HR-PCS questionnaire [15], Innovation was adopted from [16]. There were 4 items for strategic role of $\mathrm{HR} \&$ competitive advantage and 3 items each for rest of the constructs. The authors deemed fit not to include all the questions of the available scales mentioned and minor editing of the questions was done to make it more understandable, Hence, reliability and validity was checked for the constructs developed for the questionnaire. Cronbach's alpha as a measure for internal reliability was checked and found to be above 0.7 for all the constructs (refer Table II). All scales were examined for the convergent and divergent validity through exploratory and confirmatory factor analysis. The factor analysis was done with principal component extraction method and varimax rotation method. Authors found one poorly fitted item which was moved to another dimension. The test was reapplied, and results confirmed. Factor loading of above 0.5 was taken as threshold.

Table II: Reliability value of the Scale

\begin{tabular}{|l|c|c|}
\hline Scale & No. of Items & $\begin{array}{l}\text { Cronbach's } \\
\text { Alpha (a) }\end{array}$ \\
\hline Strategic role of HR & 4 & 0.75 \\
\hline $\begin{array}{l}\text { Training and } \\
\text { Development focus }\end{array}$ & 3 & 0.71 \\
\hline Innovation skills & 3 & 0.74 \\
\hline Reusability & 3 & 0.87 \\
\hline Customizability & 3 & 0.81 \\
\hline Competitive Advantage & 4 & 0.79 \\
\hline
\end{tabular}

Statistical Analysis: In an endeavor to test the proposed theory, authors have used structural equation modelling to establish relationship among the variables. The model was estimated a path model by using the AMOS software and maximum likelihood estimation methods. The constructs are being measured with reflective items as portrayed in the model. A minimum of three items per construct was maintained for optimal and accurate results. The data was interval level and multivariate normally distributed. Gaussian or normality distribution was evaluated by one sample Kolmogorov Smirnov test was conducted which provides results basis empirical cumulative distribution function. The p-value was found to be more than 0.05 and hence null hypothesis was rejected stating that the sample is normally distributed which is a mandate for SEM analysis [17].

Before the analysis was done in AMOS on SEM, exploratory analysis was conducted on the data. All the items in a construct converged well and any item with factor loading less than 0.5 was deleted. The Kaiser-Meyer-Olkin Measure of Sampling Adequacy was 0.905 which is adequate. Cronbach alpha for all the constructs was above 0.8 . The model was also run through confirmatory factor analysis in AMOS which showed estimates higher than 0.5 for each item. Convergent validity was measured, and CR value was found to be above 0.7 and Average Variance Extracted was found to be greater than 0.5 . The normality assessment was made by measuring skewness of each item which was found to be lower than 1.0.

\section{RESULT}

The direct effect of strategic HR on competitive advantage of the firm is 0.247 . The direct effect of strategic HR on training and development focus is 0.766 . Direct effect of training and development on innovation is 0.395 , on reusability is 0.591 and customizability is 0.832 . Indirect effect of training and development on competitive advantage from innovative skills is 0.081 , reusability is 0.634 and customizability is 0.547 . Beta value of direct effect of strategic HR on competitive advantage is less than the added values of indirect effect through training and development, satisfying the condition for partial mediation. Refer Table III for beta values of construct paths.

Table III: p-value from AMOS SEM analysis

\begin{tabular}{|l|r|r|r|r|r|r|}
\hline $\begin{array}{r}\mathrm{C} \\
\text { onstr } \\
\text { uct }\end{array}$ & $\begin{array}{r}\mathrm{P} \\
\text { ath }\end{array}$ & $\begin{array}{r}\text { Con } \\
\text { struct }\end{array}$ & $\begin{array}{r}\text { Esti } \\
\text { mate }\end{array}$ & S.E. & C.R & $\begin{array}{r}\text { P-val } \\
\text { ue }\end{array}$ \\
\hline $\mathrm{TD}$ & $<--$ & $\mathrm{ST}$ & 0.76 & 0.17 & 5.21 & $* * *$ \\
\hline $\mathrm{IN}$ & $<--$ & $\mathrm{TD}$ & 0.39 & 0.16 & 6.24 & 0.231 \\
\hline $\mathrm{RE}$ & $<--$ & $\mathrm{TD}$ & 0.59 & 0.18 & 6.82 & $* * *$ \\
\hline $\mathrm{CS}$ & $<--$ & $\mathrm{TD}$ & 0.83 & 0.17 & 7.16 & $* * *$ \\
\hline $\mathrm{CA}$ & $<--$ & $\mathrm{ST}$ & 0.24 & 0.10 & 6.20 & $* * *$ \\
\hline $\mathrm{CA}$ & $<--$ & $\mathrm{IN}$ & 0.08 & 0.15 & 3.08 & 0.371 \\
\hline $\mathrm{CA}$ & $<--$ & $\mathrm{RE}$ & 0.63 & 0.12 & 4.00 & $* * *$ \\
\hline $\mathrm{CA}$ & $<--$ & $\mathrm{CS}$ & 0.54 & 0.13 & 4.15 & $* * *$ \\
\hline
\end{tabular}

As per the results discussed, $\mathrm{H}_{1 \mathrm{a}}, \mathrm{H}_{1 \mathrm{~b}}, \mathrm{H}_{2 \mathrm{~b}}, \mathrm{H}_{2 \mathrm{c}}, \mathrm{H}_{3 \mathrm{a}}, \mathrm{H}_{3 \mathrm{~b}}$ and $\mathrm{H}_{3 \mathrm{c}}$ have been accepted (refer Table IV). The p-value for $\mathrm{H}_{2 \mathrm{a}}$ is higher than 0.001 and hence it is rejected. Summarizing, Strategic role of HR influences training and development focus in the organization and helps in process improvements and enhancements which lead to competitive advantage.

Table IV: Hypothesis acceptance/rejection

\begin{tabular}{|c|c|c|c|}
\hline $\begin{array}{l}\text { Hypothesis for } \\
\text { Path Analysis }\end{array}$ & Estimate & p-value & $\begin{array}{l}\text { Result of } \\
\text { Hypothesis }\end{array}$ \\
\hline $\begin{array}{l}\text { H1a: Strategic } \\
\text { role of HR } \\
\text { positively impacts } \\
\text { the competitive } \\
\text { advantage of the } \\
\text { org }\end{array}$ & 0.247 & $\begin{array}{l}\text { Less } \\
\text { than } \\
0.001\end{array}$ & $\begin{array}{l}\mathrm{H}_{1 \mathrm{a}} \\
\text { accepted } \\
\text { (Partial } \\
\text { Mediation) }\end{array}$ \\
\hline $\begin{array}{l}\text { H1b: Strategic } \\
\text { role of HR } \\
\text { positively impacts } \\
\text { training and } \\
\text { development } \\
\text { focus in the org }\end{array}$ & 0.766 & $\begin{array}{l}\text { Less } \\
\text { than } \\
\text { 0.00kek }\end{array}$ & \\
\hline
\end{tabular}




\begin{tabular}{|c|c|c|c|}
\hline $\begin{array}{l}\mathrm{H} 2 \mathrm{a}: \mathrm{T} \& \mathrm{D} \\
\text { positively impacts } \\
\text { innovation } \\
\text { capabilities of the } \\
\text { employees }\end{array}$ & 0.395 & 0.231 & $\begin{array}{l}\mathrm{H}_{2 \mathrm{a}} \\
\text { rejected }\end{array}$ \\
\hline $\begin{array}{l}\text { H2b: T\&D } \\
\text { positively impacts } \\
\text { reusability of } \\
\text { established } \\
\text { processes in other } \\
\text { similar projects }\end{array}$ & 0.591 & $\begin{array}{l}\text { Less } \\
\text { than } \\
0.001\end{array}$ & $\begin{array}{l}\mathrm{H}_{2 b} \\
\text { accepted }\end{array}$ \\
\hline $\begin{array}{l}\text { H2c: T\&D } \\
\text { positively impacts } \\
\text { customizability of } \\
\text { processes as per } \\
\text { client needs. }\end{array}$ & 0.832 & $\begin{array}{l}\text { Less } \\
\text { than } \\
0.001\end{array}$ & $\begin{array}{l}\mathrm{H}_{2 \mathrm{c}} \\
\text { accepted }\end{array}$ \\
\hline $\begin{array}{l}\text { H3a: Innovation } \\
\text { skills of } \\
\text { employees } \\
\text { positively impact } \\
\text { competitive } \\
\text { advantage of the } \\
\text { organization }\end{array}$ & 0.081 & 0.371 & $\begin{array}{l}\mathrm{H}_{3 \mathrm{a}} \\
\text { rejected }\end{array}$ \\
\hline $\begin{array}{l}\text { H3a: Reusability } \\
\text { of established } \\
\text { processes } \\
\text { positively impact } \\
\text { competitive } \\
\text { advantage of the } \\
\text { organization. }\end{array}$ & 0.634 & $\begin{array}{l}\text { Less } \\
\text { than } \\
0.001\end{array}$ & $\begin{array}{l}\mathrm{H}_{3 b} \\
\text { accepted }\end{array}$ \\
\hline $\begin{array}{l}\text { H3a: } \\
\text { Customizability } \\
\text { of processes as } \\
\text { per client needs } \\
\text { positively impact } \\
\text { competitive } \\
\text { advantage of the } \\
\text { organization. }\end{array}$ & 0.547 & $\begin{array}{l}\text { Less } \\
\text { than } \\
0.001\end{array}$ & $\begin{array}{l}\mathrm{H}_{3 \mathrm{c}} \\
\text { accepted }\end{array}$ \\
\hline
\end{tabular}

\section{DISCUSSION}

The results of path analysis for structural equation modelling suggest that strategic role of HR where HR plays crucial role in decision making and has a chair in the board room of an organization plays crucial role in creating competitive advantage. The study encapsulates the parameters that create competitive advantage in an IT firm. In IT the firm is selling its services and they are executed by human resources of the organization. This makes human resources in the IT sector as the most valued asset of the firm. The organizations which invest in the development of the employees are the ones which have a better edge in creating competitive advantage.

In IT sector the more the employees are billable to the customer, the better is the organization's economic performance. The present study has tried to take both the perspectives into account; the employee readiness and software development processes. The results of the survey-based study show that strategic role of the HR influences training and development focus of the organization. The department is a cost centre and organizations which understand the importance of investment in the upgradation of their employees, free flow of
ISSN: 2278-3075, Volume-8, Issue-9S, July 2019 information and sharing of work knowledge can create an edge for themselves in the industry.

The research results showed strong support towards $\mathrm{H}_{1 \mathrm{~b}}$, suggesting that strategic role of HR has significant impact on the training and development focus. Training and development focus have significant impact $\left(\mathrm{H}_{2 b}\right.$ and $\left.\mathrm{H}_{2 \mathrm{c}}\right)$ on reusability of processes and customizability of services for the customer and therefore on the competitive advantage $\left(\mathrm{H}_{3 \mathrm{~b}}\right.$ and $\mathrm{H}_{3 \mathrm{c}}$ ) of the firm. Firms that can customize services for their customers have a better market responsiveness and improved response to changing dynamism of the market. Firms that can encourage their employees to share knowledge and reuse it in other projects are able to maintain better margins in terms of having better cost efficiencies. Customizability facilitates process roadmap and creates ability to tailor processes as per the requirement.

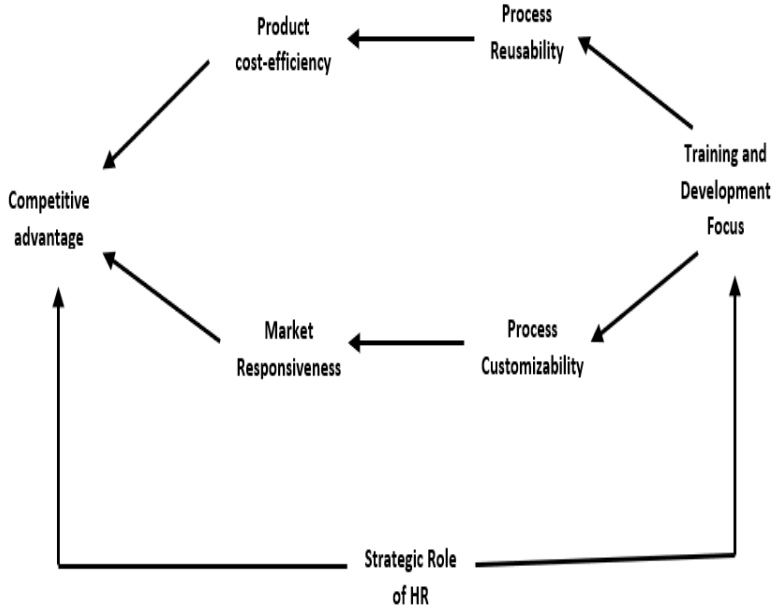

Figure II: Summary of present study (Self-created by Authors)

Managerial Implications: As the margins are pressed and firms still want to grow fast in the industry, it becomes imperative to understand what the managers should do to take the firm to the right path. From this study it has become evident that HR function in the organization needs to take the lead forward and focus on skilling the employees to invest in process improvement and enhancement. The strategy lifecycle will need to be short leading to agile processes which would necessitate fast reaction to changing market dynamics. Table V shows which decisions will get impacted by HR strategy to influence processes to give managerial implications in the firm.

Table V: Managerial implication of the concept

\begin{tabular}{llll} 
& & $\begin{array}{l}\text { Impact on } \\
\text { Reusability }\end{array}$ & \\
Business & & $\&$ & \\
Decision & HR & Customizab & Managerial \\
Impact & Strategy & ility & Implication \\
\hline
\end{tabular}


integratec
Decision to Transformati invest in on into a core $\mathrm{T} \& \mathrm{D}$

\section{function}

which is strategically aligned to business units.

\section{Become} partners in team development with business heads

\section{Implemen \\ ation of \\ T\&D}

Have

initiative approach with business heads and customers to understand need and requirement

Operational

and transformati onal HR approach to encourage employees to share best practices, create forums and culture for the same

\section{Collaborativ} e working and selection of trainings which are relevant and provide desired results of enabling firm to maintain its leading performance

Utilizing HRIS, creating forums and trainings to provide support in knowledge sharing, providing a common HR portal globally in the firm

Identifying employees based on skill and competence, providing enhanced support in the area of talent management

\section{T\&D}

Explore

activities to

get maximum varied means to deliver ROI

\section{trainings} besides the instructor led, domain and skill specific to customer needs
Workforce which is skill ready to be deployed as per the project requirement and urgency at any point in time and has high maneuverabi lity
Allow access to employees with e-learning and video-based learning to facilitate learning at the choice of their time, pace and space

\section{REFERENCES}

[1] Armstrong \& Shimizu, C. E. (2007). A Review of Approaches to Empirical Research on the Resource-Based View of the Firm. Journal of Management, 33(6), Pp. 959-986.

[2] Batt and Banerjee, R. M. (2011). The scope and trajectory of strategic HR research: evidence from American and British journals. The International Journal of Human Resource Management, Vol. 23, No.

[3] Browning Edgar Gray \& Garrett, V. F. (2009). Realising competitive Service Industries Journal, Pp 741-760.

[4] C. Zheng. (2009). Correlational Study of Organizational Innovation Capability and Two Factors:Innovation Drivers and Organizational Culture . ProQuest Dissertations and Theses database (UMI No. 3394575). , Pp. 203-209.

[5] Certo \& Peter. (1990). Case Enrichment Portfolio for Selected Cases in Strategic Management. McGraw-Hill Publishing Company.

[6] Hair et al. (2006). Multivariate data analysis.

[7] Hardesty Bearden and Carlsonc, D. M. (2007). Persuasion knowledge and consumer reactions to pricing tactics. Journal of Retailing, Volume 83, Issue 2,, Pp. 199-210. 9, Pp. 1739-1762. advantage through HRM in New Zealand service industries. The

[8] Little, B. (2014). Best practices to ensure the maximum ROI in learning and development. "Industrial and Commercial Training, Vol. 46 Iss 7, pp. 400 - 405

[9] Nidumolu \& Knotts, S. R. (1998). The Effects of Customizability and Reusability on Perceived Process and Competitive Performance of Software Firms. MIS Quarterly, Vol 22, No. 2, Pp. 105-137.

[10] Pleval, M. e. (1994). AT \& T Global Business Communications Systems: Linking HR with Business Strategy. Organizational Dynamics, 22(3), Pp. 59-72.

[11] Powell, T. C. (2001). Competitive Advantage: Logical And Philosophical Considerations. Strategic Management Journal, Pp. 875-888.

[12] Ramos-Rodríguez and Ruíz-Navarro, A.-R. J. (2004). Changes in the Intellectual Structure of Strategic Management Research: A Bibliometric. Strategic Management Journal, Vol. 25, No. 10, Pp. 981-1004.

[13] Reddington Martin \& Bondarouk, M. G. (2015). Chapter 4 Linking HR Strategy, e-HR Goals, Architectures, and Outcomes: A Model and Case Study Evidence. In Electronic HRM in Theory and Practice (pp. Pp. 55-81). Emerald publication.

[14] Sajeevanie, T. (July 2015). Strategic Human Resource Management and Theoretical Background: A Critical Review Perspective. Proceedings of the Third Asia-Pacific Conference on Global Business, Economics, Finance and Banking (AP15Singapore Conference) ISBN: 978-1-63415-751-3.

[15] Schoonover, S. C. (2000). HumanResource Competencies for the Year 2000: The Wake-Up Call. Society for Human Resource Management. Pp 27.

[16] Singh, K. (2003). Strategic HR orientation and firm performance in India. Int. J. of Human Resource Management 14:4 , Pp. 530-543.

[17] Sinkula Baker and Noordewier, J. M. (1997). A Framework for Market-Based Organizational Learning: Linking Values, Knowledge, and Behavior. Journal of the Academy of Marketing Science, Volume 25, No. 4, Pp 305-318.

[18] Sung \& Choi, S. Y. (2018). To invest or not to invest: strategic decision making toward investing in training and development in Korean manufacturing firms. The International Journal of Human Resource Management, VOL. 29, NO. 13, Pp. 2080-2105.

[19] Vlachos, I. (2008). The effect of human resource practices on organizational performance: evidence from Greece. The International Journal of Human Resource Management Vol. 19, No. 1, Pp. 74-97.

[20] Walker, J. (1990). Human Resource Strategy. Graw Hill International Edition.

[21] Wang, H.-L. (2013). Theories for competitive advantage. In Being practical with theory: a window into business research (pp. Pp. 33-43). University of Wollongong http://ro.uow.edu.au/buspapers/408.

[22] Wang, H.-L. (2014). Theories for competitive advantage. In H.-L. Wang, Being Practical with Theory: A Window into Business Research (pp. Pp. 33-43). Wollongong, Australia: University of Wollongong.

\section{AUTHORS PROFILE}

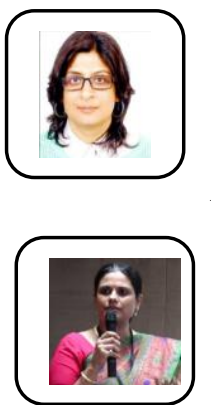

Yogita Patra is a research scholar at Amity International Business School, Amity University, India. She has fourteen years of experience in corporate with renowned organizations like Pearson and Hindustan Computers Limited (HCL). Her research interests include HR Analytics and Workforce optimization. research interest includes quality of life, sustainable development and various upcoming issues in the area of HR \&OB. She has also written research papers in international and national journals.

Dr Shruti Tripathi is Associate Professor of HR \& OB at Amity International Business School, Amity University Noida, India. She has been into teaching and training to PG students and Civil services Officers since 2001. He

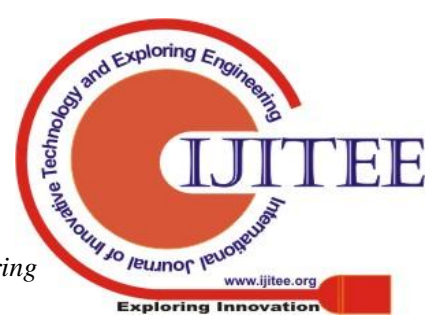

